\title{
HUBUNGAN BEBAN KERJA DAN LINGKUNGAN KERJA DENGAN STRES KERJA PERAWAT RUANGAN ICU DAN IGD
}

\author{
Isna Aglusi Badri ${ }^{1}$ \\ Fakultas Keperawatan Universitas Andalas \\ Email : isna_loushe@yahoo.co.id
}

Submitted: 22-03-2020, Reviewer: 23-03-2020, Accepted: 23-03-2020

\begin{abstract}
ABSTRAK
Stres kerja adalah suatu bentuk tanggapan seseorang, baik fisik maupun mental terhadap suatu perubahan di lingkungannya yang dirasakan mengganggu dan mengakibatkan dirinya terancam. Stres kerja perawat dipengaruhi oleh faktor lingkungan, kelebihan beban kerja, organisasi dan individu. Penelitian ini bertujuan untuk melihat hubungan beban kerja dan lingkungan kerja dengan stres kerja perawat ICU dan IGD di Rumah Sakit Harapan Bunda dan Rumah Sakit Camatha Sahidya Kota Batam. Penelitian ini menggunakan rancangan cross sectional. Sampel dalam penelitian sebanyak 47 perawat. Teknik pengambilan sampel yang digunakan adalah secara total sampling Hasil penelitian adalah perawat yang memiliki beban kerja berat sebanyak 55,3\%, perawat memiliki lingkungan yang baik 53,2\% dan perawat yang mengalami stres kerja berat sebanyak 53,2\%. Setelah dilakukan uji statistik didapatkan hubungan bermakna antara beban kerja dan lingkungan kerja dengan stres kerja perawat ( $p<0.05)$. Manajemen Rumah Sakit Harapan Bunda dan Rumah Sakit Camatha Sahidya diharapkan untuk lebih meningkatkan lingkungan kerja yang kondusif, optimalkan sarana dan prasarana dan meningkatkan hubungan interpersonal yang baik dengan perawat.
\end{abstract}

Kata Kunci : : Stres kerja, Beban kerja, Lingkungan kerja

\begin{abstract}
Job stress is a person response, both physically and mentally for a environment changing that is fell disruptive and make his / her being threatened. Job stress of nurses are effeted environmental factors, excessive workloads, organizations and individuals. This study aims to examine the relationship of workload and job stress with work environment of nursing staf ICU and IGD at Harapan Bunda Hospital and Camatha Sahidya Hospital. This study used cross sectional design. The sample consisted of 47 nurses. The sampling technique was total sampling. The result showed heavy workload proportion in 53,3\%, good enviroment proportion in 53,2\% and severe job stress proportion in 53,2\%. There is significant relationship between workload and work environment with nurse job stress $(p<0,05)$. Management of Harapan Bunda Hospital and Camatha Sahidya Hospital need move improve the condition of work environment, optimize the infrastructure and improve interpersonal relationships with nurses.
\end{abstract}

Keywords : Job stress, Workload, Work environment 


\section{PENDAHULUAN}

Rumah Sakit merupakan salah satu bentuk sarana kesehatan, baik yang diselenggarakan oleh pemerintah dan atau masyarakat yang berfungsi untuk melakukan upaya pelayanan kesehatan dasar, kesehatan rujukan dan upaya kesehatan penunjang. Keberhasilan suatu rumah sakit dalam menjalankan fungsinya ditandai dengan adanya peningkatan mutu pelayanan Rumah Sakit. Mutu pelayanan Rumah Sakit sangat dipengaruhi oleh beberapa faktor. Faktor yang paling dominan adalah sumber daya manusia (Departemen Kesehatan RI, 2001).

Sumber daya manusia merupakan sumber daya (tenaga kerja) yang dimiliki oleh individu secara efisien dan efektif serta dapat digunakan secara maksimal sehingga tercapai tujuan bersama sebuah perusahaan. Menurut Wijaya, dkk (2006) banyak jenis pekerjaan yang harus dipantau selama 24 jam salah satunya adalah layanan rumah sakit. Perawat merupakan salah satu pekerjaan yang memberikan pelayanan di rumah sakit dalam waktu 24 jam. Menurut Hamid (2001) pekerja kesehatan rumah sakit yang terbanyak adalah perawat yang berjumlah sekitar $60 \%$ dari tenaga kesehatan yang ada di rumah sakit. Perawat merupakan ujung tombak pelayanan kesehatan di rumah sakit. Perawat di rumah sakit bertugas pada pelayanan rawat inap, rawat jalan atau poliklinik dan pelayanan gawat darurat. Menurut Departemen Kesehatan RI (2001) pelayanan kesehatan meliputi pendekatan bio-psiko-sosial-spiritual

berkesinambungan.

Adanya tuntutan idealisme profesi menurut Perancis et al dalam Mark \& Smith (2011) menerangkan bahwa perawat setiap hari dapat terkena stres, yaitu konflik dengan dokter, diskriminasi, beban kerja yang tinggi, menghadapi pasien, kematian dan keluarga pasien. Perawat dihadapkan dengan tugas kerja yang berbeda, bekerja dengan shift, kondisi kerja, situasi terkait stres, penderitaan, dan kematian pasien.
Berdasarkan keterangan dari Diklat Rumah Sakit PHC Surabaya (2007) bahwa tugas dan tanggung jawab perawat di ruang kritis dan gawat darurat cukup berat, baik terhadap klien, keluarga dan dokter. Hal ini perlu kesiapan mental, fisik, pengetahuan dan keterampilan yang tinggi. Sedangkan menurut Nur'aini (2007) bekerja di ruang kritis dan gawat darurat membutuhkan kecekatan, keterampilan dan kesiagaan setiap saat. Hal ini dikarenakan tingkat keter- gantungan pasien di ruang kritis dan gawat darurat adalah sebagian sampai dengan ketergantungan total. Pasien harus selalu diobservasi setiap jam bahkan lebih sering lagi. Keadaan tersebut dapat menyebabkan stres kerja di ruang kritis dan gawat darurat.

Menurut Sri (2006) perawat juga harus sanggup mengatasi stres karena dalam dunia keperawatan tidak boleh melakukan kekeliruan sedikitpun. Perawat dalam melakukan pekerjaannya harus dapat menyesuaikan diri agar dapat melaksanakan pekerjanya tanpa mengorbankan mutu pekerjanya. Selanjutnya menurut Danang (2009) perawat bertanggung jawab terhadap tugas fisik, administratif dan menghadapi keluhan klien dalam menjalani proses keperawatan seperti kecemasan, ketegangan, kejenuhan klien dan keluarga dalam kondisi sakit kritis atau keadaan terminal.

Faktor penyebab stres yang bersumber dari tekanan psikologis tersebut, rentannya kondisi perawat terhadap stres kerja dapat juga disebabkan oleh beberapa factor yang bersumber pada pekerjaan itu sendiri, faktor yang bersumber dari organisasi tempat bekerja dan faktor eksternal di luar pekerjaan seperti lingkungan, keluarga, peristiwa krisis dalam kehidupan dan lain-lain ( Grenserg, 2002). Salah satu faktor yang bersumber pada pekerjaan diantaranya beban kerja. Beban kerja adalah semua pekrjaan yang ditanggung oleh pekerja untuk menyelesaikan pekerjaannya (Depkes RI, 2003).

Beberapa faktor yang mempengaruhi munculnya stres kerja perawat ruang kritis dan gawat darurat antara lain : kelebihan beban kerja, 
jumlah dan tingkat ketergantungan pasien, tuntutan pelayanan menjadi perawat professional, tingkat pendidikan, pengalaman sebelumnya dengan stres, kepribadian perawat dan mekanisme koping (Potter dan Perry , 2005)

Faktor stres yang sering dialami karyawan adalah berada dalam lingkungan kerja yang tidak kondusif dan tidak baik karena lingkungan kerja sangat mempengaruhi akan kinerja dan performance yang baik. Jika karyawan berada dalam lingkungan yang tidak mendukung contoh sistem kerja dan manajemen kantor yang tidak cocok dengan kepribadian karyawan, maka akan menimbulkan hambatan jalinan kekerabatan antara atasan dan rekan.

Menurut survei di Perancis ditemukan bahwa persentase kejadian stres sekitar $74 \%$ dialami perawat. Berdasarkan penelitian Mealer perawat ICU juga rentan mengalami Post Traumatic Stress Disorder (PTSD) dibandingkan dengan perawat umum yang mana didapatkan hasil bahwa dari 121 responden dari perawat umum terdapat 17 responden (14\%) yang mengalami PTSD sedangkan dari 230 perawat ICU, terdapat 54 responden (24\%) yang mengalami PTSD (Mealer, M. L 2007). Sedangkan di Indonesia menutut hasil penelitian yang dilakukan oleh Persatuan Perawat Nasional Indonesia (PPNI) tahun 2006 terdapat 50,9\% perawat mengalami stres dengan keluhan sering merasa pusing, lelah, tidak ada istirahat, beban kerja yang terlalu tinggi dan pekerjaan yang menyita waktu.

Berdasarkan hasil wawancara pada perawat di Rumah Sakit Tipe C Kota Batam tersebut pada hari Selasa tanggal 7 April 2015 didapatkan bahwa perawat ruang ICU mengatakan selama jam kerja harus mengobservasi pasien secara ketat, melakukan perawatan total yang diperlukan pasien selama jam kerja dengan beragam pekerjaan yang harus dikerjakan serta belum semua perawat memiliki ketrampilan sesuai kompetensi yang ada di ruang ICU. Selanjutnya berdasarkan hasil wawancara dengan perawat IGD mengatakan bahwa pada saat banyak pasien, sering kekurangan tenaga perawat sehingga pekerjaan meningkat. Hal tersebut mengakibatkan perawat sering mengalami mudah marah, mudah tersinggung, menurunnya konsentrasi dalam bekerja, kehilangan nafsu makan dan nyeri pinggang serta punggung.

Stres kerja dalam jangka pendek dibiarkan begitu saja tanpa penanganan yang serius membuat karyawan menjadi tertekan, tidak termotivasi dan frustasi menyebabkan karyawan bekerja tidak optimal sehingga kinerjanya pun akan terganggu sedangkan dalam jangka panjang, karyawan yang tidak dapat menahan stres kerja maka ia tidak mampu lagi bekerja. Pada tahap yang semakin parah, stres bisa membuat karyawan menjadi sakit atau bahkan akan mengundurkan diri (turnover) (Robbins, 2008)

Tujuan dari penelitian ini adalah untuk mengetahui hubungan beban kerja dan lingkungan kerja dengan stres kerja perawat ruangan ICU dan IGD di Rumah Sakit Harapan Bunda dan Rumah Sakit Camatha Sahidya Kota Batam.

\section{METODE PENELITIAN}

Penelitian ini menggunakan desain penelitian Cross sectional corelasi, merupakan rancangan penelitian dengan melakukan pengamatan pada saat bersamaan dimana peneliti akan melihat hubungan beban kerja dan lingkungan kerja dengan stres kerja perawat ICU dan IGD di Rumah Sakit Harapan Bunda dan Rumah Sakit Camatha Sahidya Kota Batam. Populasi dari penelitian ini adalah seluruh perawat ICU dan IGD di Rumah Sakit Kota Batam sedangkan sampel dari penelitian adalah perawat ICU dan IGD di Rumah Sakit Harapan Bunda dan Rumah Sakit Camatha Sahidya Kota Batam. Teknik pengambilan sampel adalah total sampling dan jumlah sampel adalah sebanyak 47 orang. Alat yang digunakan untuk mengumpulkan data adalah lembar kuesioner yang diisi oleh Perawat yang ada di ruangan ICU dan IGD. Pengolahan data dilakukan dengan proses editing, coding, scoring, entry data, tabulating dan cleaning .

\section{HASIL DAN PEMBAHASAN}

Tabel 1 
Distribusi Frekuensi Karakterisktik Perawat di

Ruangan ICU dan IGD Rumah Sakit Harapan Bunda dan Rumah Sakit Camatha Sahidya Batam Tahun $2015(n=47)$

\begin{tabular}{clcc}
\hline No & \multicolumn{1}{c}{ KarakteristikPerawat } & F & $\%$ \\
\hline 1 & Jenis Kelamin & 20 & 43 \\
& Laki-laki & 27 & 57 \\
& Perempuan & & \\
2 & Umur & 24 & 51 \\
& Remaja akhir (17-25 tahun) & 45 \\
& Dewas a awal(26-35 tahun) & 21 & 4 \\
& Dewasa akhir(36-45 tahun) & 2 & \\
\multirow{2}{*}{3} & & \\
& Pendidikan & 47 & 100 \\
& D-III Keperawatan & 0 & 0 \\
\hline & S-1 Keperawatan & 47 & 100 \\
\hline
\end{tabular}

Tabel 1 menunjukkan bahwa jenis kelamin perawat di ruangan ICU dan IGD Rumah Sakit Harapan Bunda dan Rumah Sakit Camatha Sahidya Batam tahun 2015 adalah lebih dari sebagian perawat perempuan (57\%). Perawat sebagian pada masa remaja akhir (17-25 tahun) yaitu sebanyak 51\%. Sedangkan untuk pendidikan, semuanya perawat miliki latar pendidikan D-III Keperawatan (100\%).

\section{Beban Kerja Perawat}

Tabel 2

Distribusi Frekuensi Beban Kerja Perawat di Ruangan ICU dan IGD Rumah Sakit Harapan Bunda dan Rumah Sakit Camatha Sahidya Batam Tahun $2015(\mathrm{n}=47)$

\begin{tabular}{cccc}
\hline No & Beban Kerja & F & $\%$ \\
\hline 1 & Beban Kerja & & \\
Langsung & & \\
& Ringan & 21 & 44,7 \\
& Berat & 26 & 55,3
\end{tabular}

2 Beban Kerja Tidak

\begin{tabular}{ccc}
$\begin{array}{c}\text { Langsung } \\
\text { Ringan }\end{array}$ & 21 & 44,7 \\
Berat & 26 & 55,3 \\
\hline Total & 47 & 100 \\
\hline
\end{tabular}

Tabel 2 menunjukkan bahwa persepsi perawat lebih dari setengah beban kerja langsung dan beban kerja tidak langsung perawat adalah berat $(55,3 \%)$.

\section{Lingkungan Kerja Perawat}

Tabel 3

Distribusi Frekuensi Lingkungan Kerja Perawat di Ruangan ICU dan IGD Rumah Sakit Harapan Bunda dan Rumah Sakit Camatha Sahidya Batam Tahun $2015(n=47)$

\begin{tabular}{|c|c|c|c|}
\hline No & Lingkungan Kerja & $\mathrm{F}$ & $\%$ \\
\hline \multirow[t]{3}{*}{1} & Lingkungan Kerja Fisik & & \\
\hline & Kurang Baik & 22 & 46,8 \\
\hline & Baik & 25 & 53,2 \\
\hline \multirow[t]{5}{*}{2} & Lingkungan Kerja Non & & \\
\hline & Fisik & & \\
\hline & Kurang Baik & 22 & 46,8 \\
\hline & Baik & 25 & 53,2 \\
\hline & Total & 47 & 100 \\
\hline
\end{tabular}

Tabel 3 menunjukkan untuk lingkungan fisik dan lingkungan non fisik adalah lebih dari setengah persepsi perawat lingkungan kerja adalah baik $(53,2 \%)$.

Tabel 4

Distribusi Frekuensi Stres Kerja Perawat di Ruangan ICU dan IGD Rumah Sakit Harapan Bunda dan Rumah Sakit Camatha Sahidya Batam Tahun $2015(n=47)$

\begin{tabular}{clcc}
\hline No & Stres Kerja & F & $\%$ \\
\hline 1 & Ringan & 22 & 46,8 \\
2 & Berat & 25 & 53,2 \\
\hline & Total & 47 & 100 \\
\hline
\end{tabular}

Tabel 4 menunjukkan bahwa stres kerja perawat lebih dari setengah perawat mengalami stres kerja berat ( 53,2\%).

\section{Analisa Bivariat}

Tabel 5

Hubungan Beban Kerja Dengan Stres Kerja Perawat di Ruangan ICU dan IGD Rumah Sakit Harapan Bunda dan Rumah Sakit Camatha Sahidya Batam Tahun 2015 ( $n=47)$

\begin{tabular}{llccccc}
\hline \multirow{2}{*}{ Variabel } & \multirow{2}{*}{ Kategorik } & \multicolumn{4}{c}{ Ringan } & \multicolumn{2}{c}{ Berat } & p value \\
& & $\mathrm{f}$ & $\%$ & $\mathrm{f}$ & $\%$ & \\
\hline Beban & Ringan & 15 & 71,4 & 6 & 28,6 & \\
Kerja & & & & & & $0,006^{*}$ \\
Langsung & Berat & 7 & 26,9 & 19 & 73,1 &
\end{tabular}




\begin{tabular}{|c|c|c|c|c|c|c|}
\hline Beban & Ringan & 15 & 71,4 & 6 & 28,6 & \\
\hline $\begin{array}{l}\text { Kerja } \\
\text { Tidak } \\
\text { langsung }\end{array}$ & Berat & 7 & 26,9 & 19 & 73,1 & $0,006^{*}$ \\
\hline
\end{tabular}

Tabel 5 didapatkan bahwa mayoritas perawat yang beban kerja langsung ringan memiliki stres kerja yang ringan $(71,4 \%)$, mayoritas perawat yang beban kerja langsung berat memiliki stress kerja yang berat $(73,1 \%)$. Hasil uji Chi-square menunjukkan nilai $\mathrm{p}=0,006$ OR 6,786 (95\% CI 1,88-24,49) artinya ada hubungan yang bermakna antara beban kerja langsung dengan stres kerja. Beban kerja langsung yang berat mempunyai peluang 6,786 kali untuk stres berat dibandingkan dengan beban kerja langsung ringan.

Beban kerja tidak langsung didapatkan mayoritas perawat yang beban kerja tidak langsung ringan memiliki stres kerja yang ringan $(71,4 \%)$, mayoritas perawat yang beban kerja tidak langsung berat memiliki stress kerja yang berat $(73,1 \%)$. Hasil uji Chi-square menunjukkan nilai $\mathrm{p}=0,006$ OR $6,786(95 \%$ CI $1,88-24,49)$ artinya ada hubungan yang bermakna antara beban kerja tidak langsung dengan stres kerja. Beban kerja tidak langsung berat mempunyai peluang 6,786 kali untuk stres berat dibandingkan dengan beban kerja tidak langsung ringan.

Tabel 6

Distribusi Frekuensi Hubungan Lingkungan Kerja Dengan Stres Kerja Perawat di Ruangan ICU dan IGD Rumah Sakit Harapan Bunda dan Rumah Sakit Camatha Sahidya Batam Tahun $2015(n=47)$

\begin{tabular}{|c|c|c|c|c|c|c|c|}
\hline \multirow{3}{*}{ No } & \multirow{3}{*}{ Variabel } & \multicolumn{6}{|c|}{ Stres Kerja } \\
\hline & & \multirow[t]{2}{*}{ Kategorik } & \multicolumn{2}{|c|}{ Ringan } & \multicolumn{2}{|c|}{ Berat } & \multirow[t]{2}{*}{ p value } \\
\hline & & & $\mathrm{F}$ & $\%$ & $\mathrm{~F}$ & $\%$ & \\
\hline \multirow[t]{2}{*}{1} & Lingkungan & Kurang & 6 & 27,3 & 16 & 72,7 & \multirow[b]{2}{*}{$0,026^{*}$} \\
\hline & & $\begin{array}{l}\text { baik } \\
\text { Baik }\end{array}$ & 16 & 64,0 & 9 & 36,0 & \\
\hline \multirow[t]{2}{*}{2} & Lingkungan & Kurang & 6 & 27,3 & 16 & 72,7 & \multirow[b]{2}{*}{$0,026^{*}$} \\
\hline & $\begin{array}{l}\text { Kerja non } \\
\text { fisik }\end{array}$ & & 16 & 64,0 & 9 & 36,0 & \\
\hline
\end{tabular}

* bermakna pada $\alpha=0,05$
Tabel 6 menunjukkan bahwa lingkungan kerja fisik perawat yang kurang baik yang mengalami stres kerja berat $(72,7 \%)$, mayoritas perawat yang lingkungan kerja fisik perawat baik memiliki stres kerja ringan $(64,0 \%)$. Hasil uji Chi-square menunjukkan $\mathrm{p}=0,026$ OR 0,211 (95\% CI 0,06-0,73) artinya ada hubungan yang bermakna antara lingkungan kerja fisik dengan stres kerja. Lingkungan kerja fisik kurang baik mempunyai peluang 0,2111 kali untuk stres ringan dibandingkan dengan lingkungan kerja fisik kurang baik.

Lingkungan kerja non fisik perawat yang kurang baik yang mengalami stres kerja berat $(72,7 \%)$, mayoritas perawat yang lingkungan kerja non fisik perawat baik memiliki stres kerja ringan (64,0\%). Hasil uji chi-square menunjukkan $\mathrm{p}=0,026$ OR 0,211 (95\% CI 0,060,73 ) artinya ada hubungan yang bermakna antara lingkungan kerja non fisik dengan stres kerja. Lingkungan kerja non fisik kurang baik mempunyai peluang 0,211 kali untuk stres ringan dibandingkan dengan lingkungan kerja non fisik kurang baik.

Berdasarkan hasil penelitian didapatkan bahwa beban kerja langsung dan beban kerja tidak langsung perawat sebagian besar beban kerja berat $(55,3 \%)$. Penelitian ini berbanding terbalik dengan penelitian Syamsir tahun 2007 di Rumah Sakit Dr. Tadjuddin Chalid Makasar didapatkan beban kerja perawat sebagian besar beban kerja ringan (63,5\%). Sedangkan menurut penelitian Supardi di Rumah Sakit TK II Putri hijau Kesdam Medan sebagian besar perawat mengalami stres sedang (63,9\%). Menurut penelitian Haryanti 2013 di Instalasi Gawat Darurat Rumah Sakit Semarang didapatkan beban kerja tinggi yaitu sebanyak 27 responden $(93,1 \%)$.

Pada penelitian ini didapatkan bahwa perawat mengatakan merasa terbebani dengan pekerjaannya seperti harus melakukan observasi pasien secara ketat selama jam dinas. Sementara jumlah pasien yang berkunjung banyak sehingga perawat kekurangan tenaga dibangingkan dengan pasien yang kritis yang harus diberikan asuhan keperawatan. Selain itu perawat juga melakukan pekerjaan yang beragam untuk keselamatan pasien. 
Beban kerja memberikan gambaran terhadap terjadinya stres kerja yang berbeda dimana setiap kita memiliki batasan ukuran kemampuan dalam bekerja, bila beban terlalu ringan maka timbul kebosanan dan bila terlalu berat akan menimbulkan kelelahan yang berpengaruh terhadap stres kerja (Cooper, 1983).

Faktor yang mempengaruhi beban kerja perawat adalah kondisi pasien yang selalu berubah, jumlah rata-rata jam perawatan yang sudah dibutuhkan untuk memberikan pelayanan langsung pada pasien melebihi dari kemampuan seseorang, keinginan untuk berprestasi kerja, tuntutan pekerjaan tinggi serta (Munandar, 2008). Hal ini sejalan dengan penelitian Supardi (2007) didapatkan bahwa kondisi kerja melibatkan kontribusi paling besar terhadap terjadinya stress kerja.

Berdasarkan hasil penelitian didapatkan bahwa lingkungan kerja fisik dan lingkungan non fisik sebagian besar memiliki lingkungan baik (53,2\%). Menurut penelitian Nur Abib Asriyanto tahun 2013 di CV Kalika Intergraha di Semarang bahwa sebagian besar lingkungan baik baik (64\%). Sedangkan menurut penelitian Laila Mutia Heriani tahun 2007 di PT Persero Unit Pelayanan Blimbing Malang bahwa sebagian besar lingkungan kerja sedang $(75 \%)$.

Setiap karyawan dituntut untuk dapat melaksanakan pekerjaan sesuai dengan jabatan yang dipegang dan beradaptasi dengan lingkungan serta rekan kerja yang memiliki karakter berbeda-beda. Interaksi antara individu dalam lingkungan kerja dapat menimbulkan dampak negative yang memicu terjadinya konflik dan masalah dalam pekerjaan dan dampak positif yaitu terciptanya kondisi lingkungan kerja yang dinamis karena adanya penyesuaian terhadap tantangan dalam lingkungan internal organisasi dan eksternal karena pengaruh globalisasi, ledakan informasi melalui teknologi, obsesi kualitas, yang dapat menimbulkan terjadinya konflik di tempat kerja (Anatan, 2009).

Lingkungan kerja yang buruk berpotensi menjadi penyebab karyawan mudah jatuh sakit, mudah stress, sulit berkosentrasi dan menurunnya produktivitas kerja. Jika ruangan kerja tidak nyaman, panas, cahaya, suhu, udara terpolusi, ruangan kerja terlalu padat, lingkungan kerja kurang bersih akan berpengaruh terhadap kerja karyawan.

Berdasarkan hasil penelitian didapatkan bahwa sebagian besar perawat $(53,2 \%)$ mengalami stres berat. Sedangkan menurut penelitian Sukma Noor Akbar tahun 2013 di Rumah Sakit Banjarbaru didapatkan perawat sebagian besar mengalami stress kerja sedang (50,85\%). Menurut penelitian Haryanti 2013 di Instalasi Gawat Darurat Rumah Sakit Semarang didapatkan stres kerja perawat adalah stres sedang $(82,8 \%)$.

Pada penelitian ini didapatkan bahwa lebih dari sebagian $(66,6 \%)$ perawat merasa tertekan dengan pekerjaannya. Hal ini disebabkan oleh pekerjaan yang banyak dan tidak sesuai dengan rencana karena lebih dari sebagian perawat $(53,2 \%)$ perawat mengatak kalau berganti-ganti rencana. Perasaan tertekan yang dirasakan oleh sebagian besar perawat membuat perawat kehilangan konsentrasi dalam melakukan pekerjaan. Jumlah kunjungan yang sekarang sudah meningkat membuat perawat tidak cukup waktu untuk menyelesaikan pekerjaan seperti pembuatan asuhan keperawatan yang lengkap.

Berdasarkan dengan hasil kuesioner juga dapat dilihat bahwa lebih dari sebagian perawat merasa merasa kecewa dengan hasil pekerjaannya. Sebagian besar $(76,6 \%)$ merasa jenuh dengan pekerjaannya. Kejenuhan yang dirasakan perawat karena perawat yang berada di ruangan ICU dan IGD sering melakukan pekerjaan yang terlalu menoton seperti mengontrol TTV pasien dengan jarak waktu yang singkat.

Secara gejala biologis perawat di ruangan ICU dan IGD Rumah Sakit Harapan Bunda dan Rumah Sakit Camatha Sahidya Kota Batam juga merasakan hal-hal yang memicu untuk terjadinya stres kerja. Lebih dari sebagian perawat merasa sakit perut/nyeri pada perut saat melakukan pekerjaan dan merasa otot kaku saat / setelah melakukan pekerjaan. Lebih dari sebagian perawat juga merasakan kehilangan nafsu makan sebelum / sesudah melakukan pekerjaan dan perut terasa mulas, tegang dan kembung saat melakukan pekerjaan. Selain itu lebih dari sebagian perawat merasa nyeri punggung, nyeri pinggang, betis terasa pegal dan persendian terasa sakit setelah melakukan pekerjaan. 
Dilihat dari gejala sosial perawat di ruangan ICU dan IGD Rumah Sakit Harapan Bunda dan Rumah Sakit Camatha Sahidya Kota Batam sering mengeluh mudah tersinggung sehingga perawat merasa adanya ketegangan dalam berinterkasi dengan tim kesehatan lain. Perawat juga mudah marah tanpa sebab yang berarti.

Stres merupakan respon tubuh yang bersifat tidak spesifik terhadap setiap tuntutan atau beban atasnya. Stres dapat muncul apabila seseorang mengalami beban atau tugas berat dan orang tersebut tidak dapat mengatasi tugas yang dibebankan. Tubuh akan berespon dengan tidak mampu terhadap tugas tersebut sehingga orang tersebut dapat mengalami stres kerja (Hidayat, 2011). Stres kerja perawat dapat terjadi apabila perawat dalam bertugas mendapatkan beban kerja yang melebihi kemampuannya sehingga perawat tersebut tidak mampu memenuhi atau menyelesaikan tugasnya, maka perawat tersebut dikatakan mengalami stres kerja. Manifestasi dari stres kerja perawat antara lain akibat karakterisasi pasien, pengkajian terhadap pasien, dan aspek lingkungan kerja yang mengganggu merupakan langkah awal dalam menangani masalah-masalah yang datang mengenai tingkat kepadatan ruangan emergency, efisiensi pelaksanaan tugas, serta adanya tuntutan untuk menyelamatkan pasien (Levin et al, 2004).

Apabila stres mencapai titik puncak yang kira-kira sesuai dengan kemampuan maksimum kinerja karyawan maka pada titik ini stres tambahan cenderung tidak menghasilkan perbaikan kinerja selanjutnya bila stres yang dialami karyawan terlalu besar, maka kinerja akan mulai menurun, karena stres tersebut mengganggu pelaksanaan kerja karyawan dan akan kehilangan kemampuan untuk mengendalikannya atau menjadi tidak mampu untuk mengambil keputusan dan perilakunya menjadi tidak menentu. Akibat yang paling ekstrim adalah kinerja menjadi nol, karyawan mengalami gangguan, menjadi sakit dan tidak kuat lagi untuk bekerja, menjadi putus asa, keluar atau menolak bekerja (Munandar, 2008).

Stres dapat terjadi pada hampir semua pekerja, baik tingkat pimpinan maupun pelaksana. Kondisi kerja yang lingkungannya tidak baik sangat potensial untuk menimbulkan stres bagi pekerjanya. Stres dilingkungan kerja memang tidak dapat dihindarkan, yang dapat dilakukan adalah bagaimana mengelola, mengatasi atau mencegah terjadinya stres tersebut, sehingga tidak menganggu pekerjaan (Notoatmodjo, 2002).

Berdasarkan hasil penelitian didapatkan bahwa perawat yang beban kerja langsung dan beban kerja tidak langsung berat dengan stres kerja tinggi sebanyak 19 perawat $(73,1 \%)$. Perawat yang beban kerja langsung dan beban kerja tidak langsung ringan dengan stres kerja ringan sebanyak 15 perawat $(71,4 \%)$.

Pada penelitian ini beban kerja langsung didapatkan sebagian perawat mengatakan bahwa merasa terbebani saat mengobservasi pasien secara ketat selama jam kerja. Walaupun itu merupakan salah satu pekerjaannya sebagai seorang perawat namun perawat di ruangan ICU dan IGD merasa berat untuk mengerjakan. Selain harus melakukan observasi pasien secara ketat, perawat juga harus banyak melakukan pekerjaan demi keselamatan pasien. Pekerjaan yang dilakukan bukanlah pekerjaan yang mudah karena tindakan-tindakan yang dilakukan oleh perawat yang ada di ICU dan IGD merupakan pekerjaan atau tindakan yang akan menyelatkan pasien. Hal ini dapat dilihat dari hasil kuesioner bahwa tindakan tersebut merupakan beban kerja yang harus dilakukan oleh perawat.

Dilihat dari beban kerja tidak langsung perawat didapatkan bahwa perawat merasa tidak mampu mengimbangi sulitnya pekerjaan. Perawat merasa sulit bukannya kurang ilmu pengetahuan namun karena pengalaman yang sedikit saat berdinas di ruangan ICU dan IGD. Sebagian perawat mengatakan bahwa penempatan kerja langsung ditempatkan di ruangan ICU dan IGD setelah mengalami orientasi.

Perawat merasa beban kerja yang dibebakan kepada perawat terlalu besar dan sulit untuk mereka lakukan sehingga perawat lebih cendrung mengalami stres kerja. Menurut perawat pemimpin kurang memperhatikan dan kurang memberi dukungan dalam menyelesaikan pekerjaan. Lebih dari sebagian perawat mengatakan bahwa komunikasi dengan pimpinan dan karyawan lainnya kurang. Selain komunikasi perawat juga mengatakan belum pernah mengikuti pelatian yang terkait dengan perawatan yang diberikan di ruangan IGD dan ICU seperti 
pelatihan PPGD, BTCLS dan pelatihan lainnya yang berhubungan dengan penanggan pasien.

Dilihat dari jumlah kunjungan dan jumlah perawat yang berdinas sering tidak sesuai. Dimana untuk perawat yang berdinas di ruangan IGD harus dihadapkan dengan pasien yang beraneka ragam. Mulai dari pasien demam tinggi, keracunan, sesak nafas, kecelakaan lalu lintas dan lainnya. Sementara pasien dilihat dari tingkat ketergantungannya ada yang selfcare, partial cara dan totalcare. Sebagaimana didapatkan bahwa pasien yang banyak datang adalah pasien yang total care seperti pasien korban kecelakaan lalu lintas yang butuh diobservasi selama 3 jam pertama.

Walaupun pasien yang banyak datang adalah korban kecelakaan tidak tertutup kemungkinan pasien lain juga banyak yang datang misalnya seperti pasien dengan keracunan minuman keras. Pasien dengan keracunan minuman keras sangat butuh pengawasan yang intens sehingga perawat memang harus mengawasi pasien dan tidak boleh terlengah. Pasien dengan keracunan minuman keras membutuhkan banyak tindakan seperti menjaga jalan nafas karena orang yang keracunan methanol dapat beresiko terjadi aspirasi ke dalam paru-paru. Menjaga jalan nafas adalah menjamin bahwa jalan masuknya udara ke paru tidak terhambat sehingga kebutuhan oksigen kedalam tubuh terpenuhi. Memberikan banyak minum untuk menghindari terjadi dehidrasi dan mengurangi kadar racun didalam tubuh.

Tindakan keperawatan tersebut tidak akan bisa dilakukan oleh perawat secara bersamaan dan harus intens satu perawat dan satu pasien. Sementara yang didapatkan di lapangan pasien datang sering dengan waktu yang bersamaan sehingga triase harus dilakukan oleh perawat. Terkadang pasien dan keluarga pasien yang tergolong prioritas ketiga ( hijau ) seperti pasien dengan cedera minor dan tingkat penyakit yang tidak membutuhkan pertolongan segera serta tidak mengancam nyawa dan tidak menimbulkan kecacatan mendesak perawat untuk melakukan tindakan dengan segera.

Tuntutan pasien dan keluarga membuat perawat akan terbebani dalam melakukan tindakan karena sebagai sebagai seorang perawat dia tidak boleh membeda-bedakan pesien dan memilah pasien sesuai dengan kebutuhan ataupun penanganannya. Sementara yang dihadapi oleh perawat berbagai desakan yang harus perawat lakukan secara bersamaan. Perawat yang dinas dalam satu shift hanya ada 3 sampai 4 orang.

Hal yang sama juga harus dilakukan oleh perawat yang dinas di ruangan ICU Rumah Sakit. Pasien yang dirawat di ruangan ICU adalah pasien yang membutuhkan tindakan resusitasi jangka panjang yang meliputi dukungan hidup untuk fungsi-fungsi vital seperti airway ( fungsi jalan napas ), breathing ( fungsi pernapasan ), circulating ( fungsi sirkulasi ), brain ( fungsi otak ) dan fungsi organ lain, disertai dengan diagnosis dan terapi definitive. Jumlah pasien di ICU bisa mencapai 3 orang dengan berbagai diagnosa medis dan keluhan. Berbagai keluhan pasien membuat berbagai tindakan juga yang harus dilakukan oleh perawat.

Sarafino ( dalam Intam, 2009 ) menjelaskan bahwa beberapa kondisi menyebabkan pekerjaan perawat menjadi sangat menekan. Beban kerja yang berat, keharusan untuk selalu berhubungan dengan masalah hidup atau mati dan gambaran tentang konsekuensi yang berat yang harus ditanggung jika melakukan kesalahan pada beberapa bagian di rumah sakit seperti bagian ICU dan IGD, keputusan harus dibuat dengan cepat, dilaksanakan segera dan tepat. Selain itu perawat sering berhubungan dengan kondisi kematian atau menjelang ajal yang menakutkan.

Beban kerja tidak terlepas dari masingmasing individu perawat karena setiap individu memiliki beban kerja masing-masing, dimana beban kerja yang tidak sesuai dapat menimbulkan stres kerja. Bila terlalu berat akan menimbulkan kelelahan dan stres kerja sedangkan beban kerja terlalu ringan akan menimbulkan kebosanan (Martha Davis, 2012 ).

Setiap orang pernah stres dan akan mengalaminya, akan tetapi kadarnya berbedabeda serta dalam jangka waktu yang tidak sama (Hardjana, 2004). Selye (1956 dalam Suliswati, 2005) menyatakan bahwa stres merupakan tanggapan menyeluruh dari tubuh baik fisik maupun mental terhadap setiap tuntutan ataupun perubahan yang mengganggu, mengancam rasa aman dan harga diri individu. Pengalaman stres adalah pengalaman pribadi dan bersifat subjektif. 
Stres terjadi apabila individu menilai situasi yang ada pada dirinya adalah situasi yang mengancam.

Menurut Roy (1991) bahwa faktor beban kerja termasuk di dalam stimulus fokal dimana secara langsung berhadapan dengan seseorang dan responnya segera. Perawat IGD yang merasa beban kerjanya tinggi akan langsung berespon untuk beradaptasi dengan kondisi yang ada. Berbagai keluhan fisik yang dirasakan merupakan respon kelelahan dari beratnya beban kerja di ruang IGD. Berdasarkan penelitian dari Rodrigues (2010) bahwa ada hubungan antara beban kerja dan tingkat stres perawat IGD, semakin tinggi beban kerja maka semakin tinggi juga tingkat stress perawat.

Menurut Manuaba (2000), akibat beban kerja yang terlalu berat dapat mengakibatkan seorang pekerja menderita gangguan atau penyakit akibat kerja. Beban kerja yang terlalu berlebihan akan menimbulkan kelelahan baik fisik atau mental dan reaksi-reaksi emosional seperti sakit kepala, gangguan pencernaan dan mudah marah. Sedangkan pada beban kerja yang terlalu sedikit dimana pekerjaan yang terjadi karena pengulangan gerak akan menimbulkan kebosanan, rasa monoton. Kebosanan dalam kerja rutin sehari-hari karena tugas atau pekerjaan yang terlalu sedikit mengakibatkan kurangnya perhatian pada pekerjaan sehingga secara potensial membahayakan pekerja. Beban kerja yang berlebihan atau rendah dapat menimbulkan stres kerja.

Banyaknya pekerjaan yang melebihi kapasitas menyebabkan kondisi fisik perawat di ICU dan IGD mudah lelah dan mudah tegang. Pelayanan keperawatan di ruang ICU dan IGD sangat kompleks, dimana membutuhkan kemampuan secara teknis dan pengetahuan yang lebih. Beban pekerjaan yang begitu banyak pemenuhan kebutuhan, penanganan masalah dan pada akhirnya sangat menguras energi baik fisik ataupun kemampuan kognitif. Kondisi perawat ICU dan IGD yang stres dengan adanya beban pekerjaan yang sudah berat hendaknya tidak ditambah lagi dengan beban lain di luar tugas sebagai perawat ICU dan IGD. Sebagai contoh adalah beban bimbingan mahasiswa praktek, beban pengurus organisasi, atau beban lain yang pada akhirnya semakin memperberat, sehingga tingkat stres perawat semakin meningkat.
Beban kerja berlebih dapat menyebabkan stres. Penelitian tentang stres perawat ICU dan IGD yang dilakukan di Malaysia oleh Lexshimi (2007), yang hasilnya menunjukkan bahwa $100 \%$ perawat yang menjadi responden mengatakan pernah mengalami stres selama bertugas di ruang ICU dan IGD. Mereka mengalami keluhan sakit kepala, nyeri dada, nyeri perut, bahkan ada yang menyampaikan kehilangan libido. Dari responden didapatkan bahwa yang menyebabkan mereka stres diantaranya adalah: beban bekerja dengan alat canggih yang sangat menegangkan, adanya ketidaknyamanan bekerjasama dengan staf lain dan kurangnya pengalaman bekerja di ruang ICU dan IGD.

Beban kerja yang ditanggung oleh perawat IGD berbeda dengan di ruang rawat yang lain. Perawat sangat merasa terbeban karena harus memberikan pelayanan keperawatan ekstra ketat dan cepat untuk menyelamatkan nyawa pasien. Selain itu dengan pemantauan dan pencatatan kondisi pasien secara rutin dan kontinyu juga merupakan beban tersendiri. Secara psikologis ada beban untuk dapat mempertahankan kondisi pasien supaya tidak tambah memburuk. Terhadap keluarga pasien perawat juga merasa terbeban untuk selalu menyampaikan segala kondisi pasien secara jujur. Beban yang dirasakan perawat IGD akhirnya menyebabkan adanya suatu tekanan secara terus menerus yang memicu terjadinya stres kerja.

Berdasarkan hasil penelitian didapatkan bahwa perawat yang lingkungan kerja fisik dan lingkungan kerja non fisik kurang baik dengan stres kerja berat sebanyak 16 perawat $(72,7 \%)$. Perawat yang lingkungan kerja fisik dan lingkungan kerja non fisik baik dengan stres kerja ringan sebanyak 16 perawat $(64,0 \%)$.

Dilihat dari lingkungan fisik lebih dari sebagian perawat menyatakan bahwa warna cat tempat bekerja mereka kurang memperbesar efisiensi kerja. Selain itu perawat juga mengatakan bahwa kurang setuju dengan penerangan yang ada di ruangan ICU dan IGD karena kurang terang sehingga terhalang saat melakukan tindakan pekerjaan. Perawat juga merasakan bahwa ruangan tempat mereka bekerja kurang bersih mengakibatkan penurunan semangat dalam bekerja. 
Lingkungan fisik seharusnya memberikan motivasi kepada perawat ataupun tenaga kesehatan lain yang bekerja di ruangan tersebut. Terkadang kita menganggap lingkungan fisik adalah hal yang sepele namun semua itu sangat memberi arti bagi individu yang ada di ruangan tersebut. Kondisi lingkungan kerja dikatakan baik atau sesuai apabila perawat dapat melaksanakan kegiatan secara optimal, sehat, aman dan nyaman. Kesesuaian lingkungan kerja dapat dilihat akibatnya dalam jangka waktu yang lama, lebih jauh lagi lingkungan kerja yang kurang baik dapat menuntut tenaga kerja dan waktu yang lebih banyak dan tidak mendukung terhadap pekerjaan yang mereka kerjakan.

Lingkungan non fisik tempat perawat bekerja juga akan mempengaruhi terjadinya stres kerja. Lebih dari sebagian perawat menyatakan kalau pimpinan kurang memberikan perhatian dan dukungan dalam menyelesaikan pekerjaan. Kurang dari sebagian perawat juga menyatakan bahwa memiliki komunikasi yang baik dengan pimpinan dan karyawan lainnya.

Perawat yang bekerja di lingkungan kerja yang mendukung untuk bekerja maka secara optimal akan menghasilkan kinerja yang baik, sebaliknya jika seorang perawat bekerja dalam lingkungan kerja yang tidak memadai dan tidak mendukung untuk bekerja maka secara optimal akan membuat perawat yang bersangkutan menjadi malas, cepat lelah sehingga kinerja perawat tersebut akan rendah.

Lingkungan kerja yang kurang baik dapat menimbulkan gangguan dan ancaman, dalam lingkungan kerja seperti ini akan menyebabkan perawat menjadi pelupa, lebih banyak kesalahan dalam aktivitas dan penurunan kemampuan dalam membuat rencana (Abraham, 2009). Perubahan kondisi kerja menimbulkan reaksi pekerja untuk dapat menyesuaikan diri dalam kondisi yang ada. Apabila pekerja kurang mampu beradaptasi dengan kondisi kerja yang ada maka akan cenderung mengalami stres kerja (Anoraga, 2001).

Lingkungan kerja akan mempengaruhi timbulmya stres karena perubahan lingkungan akan merangsang sikap pekerja untuk dapat menyesuaikan diri dengan lingkungan kerja (Susilawati, 2004). Lingkungan kerja tidak hanya secara fisik saja namun lingkungan non fisik juga sangat mempengaruhi timbulnya stres kerja. Dalam menjalani kehidupan kita tidak akan luput dari kerjasama dengan orang disekitar kita. Hal itu juga akan dirasakan oleh perawat yang bekerja di ruangan ICU dan IGD Rumah Sakit.

Lingkungan kerja fisik dalam suatu perusahaan merupakan suatu kondisi pekerjaan untuk memberikan suasana dan situasi kerja karyawan yang nyaman dalam pencapaian tujuan yang diinginkan oleh suatu perusahaan. Kondisi kerja yang buruk berpotensi menjadi penyebab karyawan mudah jatuh sakit, mudah stres, sulit berkonsentrasi dan menurunnya produktivitas kerja. Bayangkan saja, jika ruangan kerja tidak nyaman, panas, sirkulasi udara kurang memadai, ruangan kerja terlalu padat, lingkungan kerja kurang bersih, berisik, tentu besar pengaruhnya pada kenyamanan kerja karyawan. alam mencapai kenyamanan tempat kerja antara lain dapat dilakukan dengan jalan memelihara prasarana fisik seperti seperti kebersihan yang selalu terjaga, penerangan cahaya yang cukup, ventilasi udara, suara musik dan tata ruang kantor yang nyaman. Karena lingkungan kerja dapat menciptakan hubungan kerja yang mengikat antara orang- orang yang ada di dalam lingkungannya (Nitisemito 1982).

Hubungan baik dengan sesama perawat akan mempengaruhi kinerja perawat tersebut. Dengan adanya hubungan baik sesama perawat di suatu ruangan akan mempermudah dalam melakukan tindakan dan saling berkoordinasi. Jika hubungan antara perawat dengan perawat tidak baik maka tidak dalam melakukan pekerjaan tidak ada koordinasinya. Hubungan baik ini tidak hanya antara perawat dengan perawat saja namun perawat dengan tenaga kesehatan lainnya juga harus dibina apalagi dengan pimpinan.

Pada kenyataannya sekarang yang kita temui di Rumah Sakit Pimpinan sangat jarang melakukan supervisi kepada bawahannya. Pimpinan hanya terfokus ke administrasi sebuah Rumah Sakit tanpa terjun langsung melihat dan mendengar keluh kesah perawat yang memberikan pelayanan kepada pasien.

Pihak manajemen perusahaan juga hendaknya mampu mendorong inisiatif dan kreatifitas. Kondisi seperti inilah yang selanjutnya menciptakan antusiasme untuk 
bersatu dalam organisasi perusahaan untuk mencapai tujuan perusahaan dengan meningkatkan kinerja karyawan.

Fraser (1992) menjelaskan bahwa $74 \%$ perawat mengalami kejadian stres, yang mana sumber utamanya adalah lingkungan kerja yang menuntut kekuatan fisik dan keterampilan. Stres adalah gangguan pada tubuh dan pikiran yang disebabkan oleh perubahan dan tuntutan kehidupan, yang dipengaruhi baik oleh lingkungan maupun penampilan individu di dalam lingkungan tersebut (Sunaryo, 2002). Sarafino (Smet, 1994) menyebutkan stres kerja dapat disebabkan karena lingkungan fisik yang terlalu menekan, kurangnya kontrol yang dirasakan, kurangnya hubungan interpersonal, dan kurangnya pengakuan terhadap kemajuan pekerja. Efek stres dapat berimplikasi pada perubahan yang cukup luas dalam perilaku, suasana hati, kemampuan untuk melakukan tugas-tugas mental (seperti berpikir, penalaran logis, pemecahan masalah dan pengambilan keputusan) dan fungsi neurofisiologis (Agrawal, 2001).

\section{SIMPULAN}

Berdasarkan hasil penelitian hubungan beban kerja dan lingkungan kerja dengan stres kerja perawat ICU dan IGD di Rumah Sakit Tipe C Batam tahun 2015 dapat diambil kesimpulan :

1. Lebih dari setengah perawat ICU dan IGD Rumah Sakit Tipe C Kota Batam tahun 2015 mengalami beban kerja langsung dan beban kerja tidak langsung berat.

2. Lebih dari setengah perawat ICU dan IGD Rumah Sakit Harapan Bunda dan Rumah Sakit Camatha Sahidya Batam tahun 2015 mengalami lingkungan kerja fisik dan lingkungan non fisik yang baik.

3. Lebih dari setengah perawat ICU dan IGD Rumah Sakit Harapan Bunda dan Rumah Sakit Camatha Sahidya Batam tahun 2015 mengalami stres kerja yang berat.

4. Adanya hubungan antara beban kerja perawat dengan stres kerja perawat ICU dan IGD di Rumah Sakit Harapan Bunda dan Rumah Sakit Camatha Sahidya Batam tahun 2015.

5. Adanya hubungan antara lingkungan kerja perawat dengan stres kerja perawat ICU dan IGD di Rumah Sakit Harapan Bunda dan
Rumah Sakit Camatha Sahidya Batam tahun 2015.

\section{DAFTAR PUSTAKA}

Andarika, R. 2004. Burnout Pada Perawat Puteri RS St. Elizabeth Semarang Ditinjau Dari DukunganSosial.JurnalPsyche. Vol. 1 No. 1, Juli 2004

Anoraga,Panji, 2001. Psikologi Kerja. PT.RinekaCipta,Jakarta

Azwar, A. 1996. Pengantar Administrasi Kesehatan. Jakarta: Bina Rupa Aksara

Danang, P (2009). Hubungan Stres Kerja Dengan Adaptasi Pada Perawat di Instalasi Gawat Darurat RSUD Pandan Arang. Diakses pada tanggal 23 Maret 2014 dari http://etd.eprints.ums.ac.id

Departemen Kesehatan RI (2001). Rencana Strategi Pembangunan Kesehatan 20012004. Jakarta. Departemen Kesehatan RI.

Diklat Rumah Sakit PHC Surabaya (2007). Materi Pelatihan Perawat ICU (Intensive Care Unit). Surabaya : RSPS.

Gibson,Ivancevich, Donnelly.(1996). Organisasi, Perilaku,Struktur, Proses. BinaRupa Aksara. Jakarta

Golizeck, A. (2005). Second Manejemen Stres. Jakarta. Bhuana Ilmu Populer.

Hamid, A, Y . 2001. Rencana Strategik Keperawatan PPNI.

Jayanti, N. (2009). Penyelesaian Hukum dan Malpraktek Kedokteran. Yogyakarta. Pustaka Yustisia.

Mark, G., \& Smith, A.P., 2011. Occupational stress, job characteristics, coping, and the mental health of nurses. Journal of Health Psychology, Vol 1, No 1, 1-17.

Martina, A. (2012). Gambaran Tingkat Stres Kerja Perawat di Ruang Rawat Inap 
Rumah Sakit Paru Dr. Moehammad Goenawan Partowidigdo Cisarua Bogor. Tesis Fakultas Ilmu Keperawatan Universitas Indonesia.

Mealer, M.L., et al.,(2007). Increased Prevalence of Post-traumatic Stress Disorder Symptoms in Critical Care Nurses, American Journal of Respiratory \& Critical Care Medicine, 175(1), 693-697

Menteri Kesehatan Republik Indonesia, 2010, Peraturan Menteri Kesehatan Nomor : 340/Menkes/PER/III/2010 tentang Klasifikasi Rumah Sakit. Jakarta: Departemen Kesehatan

Munandar, S. 2008. Psikologi Industri dan Organisasi. Jakarta : UI Press

National Safety Council . (2004). Manajemen Stres National Safety Council. Jakarta EGC

Nur'aini (2007). Aktivitas Program Intervensi Pengendalian Stres Kerja Perawat dalam Upaya Meningkatkan Mutu Pelayanan Keperawatan diUnit Perawatan Intensive Rumah sakit Haji Medan. Program Studi Magister Kesehatan masyarakat Program
Megister Kesehatan Kerja Program Pasca Sarjana, Universitas Sumatera Utara.

Nursalam. (2001). Metodologi Riset Keperawatan. Infomedika. Jakarta.

Nursalam. (2003). Pendekatan Praktis Metodologi Riset Keperawatan. Jakarta. Sagung Seto

Potter, P.A \& Perry, A. G. (2005). Buku Ajar Fundamental Keperawatan Vol 1. Jakarta. EGC

Purwanto, S. (2007). Kualitas Pelayanan Keperawatan. http:klinis.wordpress.com

Robbins, S ( 2008 ). Perilaku Organisasi. Jakarta. Salemba Empat

Sondang, S (2003). Teori dan Praktek Kepemimpinan. Jakarta. Rineka Cipta

Sri Inawati (2006). Mengapa Perawat dibutuhkan?.www//http:kaltengpos.com

Waluyo, M. (2009). Psikologi Teknik Industri. Jakarta. Graha Ilmu 